\title{
2. Edvard Lidforss och katalanskan
}

\author{
Dan Nosell
}

Volter Edvard Lidforss föddes den 11 februari 1833 i Mora. Föräldrarna var skolprästen Abraham Volter Lidforss och Johanna Jakobina Maria Grönvall. Efter studier vid läroverket i Västerås påbörjade Lidforss sina studier vid Uppsala universitet 1851, först i juridik och senare i moderna språk, och tog sin fil.kandexamen 1863. I Uppsala hade han studerat för Böttiger och Bernhard Elis Malmström, professor i estetik samt litteratur- och konsthistoria. 1862 publicerade han två korta uppsatser i engelska och tyska, $A$ survey of the English conjugation och Beiträge zur Kenntnis von dem Gebrauch des Konjunktivs im Deutschen. Under studietiden hade han tjänstgjort som läroverkslärare, bl.a. i Norrköping 1855-1859, och där lärt känna sin blivande hustru Anne-Marie Swartling, dotter till en grosshandlare i staden. 1864 tillträdde Lidforss ett lektorat i moderna språk vid Högre lärarinneseminariet i Stockholm. Under sin lärargärning publicerade han även ett antal läroböcker i franska och tyska för undervisningen vid läroverken (Lidforss 1860, 1863, 1867), och tack vare ett statligt resestipendium fick han även möjlighet att 1864 genomföra en studieresa till Tyskland, Österrike, Schweiz och Frankrike. 1866 disputerade Lidforss i nyeuropeisk lingvistik i Lund med en skrift på 36 sidor med titeln Observations sur l'usage syntaxique de Ronsard et de ses contemporains. Därefter blir Lidforss utnämnd till t.f. professor i detta ämne vid Lunds universitet.

Intresset för de moderna språken som undervisningsämnen i skolorna och på universiteten växte fram under början av 1800-talet. Man skulle kunna säga att detta intresse var en utlöpare av såväl upplysningstiden som de romantiska strömningar som blev alltmer dominerande. Herders idéer om folkspråken spelade en stor roll liksom praktiska överväganden av olika slag. Latinets roll som vetenskapens språk blev allt mindre och särskilt för små språkområden blev det därför nödvändigt att sprida kunskaperna i de större moderna språken i vidare kretsar även utanför adeln. Ett exempel på detta är det vid den tiden svenska universitetet i Greifswald där det redan i mitten av 1700-talet framställdes tvåspråkiga ordböcker, både tysk-svenska och fransk-svenska. 
I Sverige togs de första stegen mot inrättandet av studiet av de moderna språken vid universiteten i Lund 1811 då Matthias Norberg, professor i grekiska och österländska språk, gav universitetet en donation vars avkastning skulle användas till en professur i levande språk, den s.k. Norbergska professuren. Det stipulerades att innehavaren skulle bli Norbergs systerson, sjökaptenen Jonas Stecksén. Eftersom han saknade formell utbildning i dessa ämnen fick han 1815 genomgå en disputation där han lade fram arbeten om tyska, franska och engelska ämnen. Han blev dock inte medlem i konsistoriet och kollegorna behandlade honom ofta med ringaktning (Sundell 2011: 58). Han efterträddes 1840 av Carl August Hagberg och då omfattade professuren även estetik med litteraturhistoria. I Uppsala hade Atterbom 1835 tillträtt en professur i dessa ämnen och när denna lärostol 1858 delades tillträdde Carl Wilhelm Böttiger som professor i nyeuropeisk lingvistik och modern litteratur. I Lund inrättades en liknande professur vars innehavare under åren 1860-1876 var Emanuel Olde.

Det är först med Theodor Hagberg i Uppsala och Edvard Lidforss i Lund som man kan säga att dessa professurer får en mer modern inriktning med innehavare som ägnar sig åt ämnenas kärna. Men man bör också hålla i minnet hur bred denna professur var och Lidforss intresse vid den här tiden verkar i första hand vara riktat mot de germanska språken. Detta intresse omfattade också gotiskan, vilket visar hur viktigt det var att kunna visa att även ämnet nyeuropeisk lingvistik vilade på en historisk grund. Det verkar till och med som om just detta var anledningen till att Lidforss gör den resa som kom att spela en avgörande roll för hans livsgärning. Lidforss hade läst en reseskildring från Spanien skriven av en dominikanermunk vid namn Jean-Baptiste Labat, Voyages du Père Labat en Espagne 1705-1706. Där beskriver denne ett besök i ett kartusianerkloster i Sevilla (Labat 1923: 200):

Nous vîmes la bibliothèque. Les réligieux prétendaient avoir là vingt mille volumes, presque tous reliés en parchemin, à la mode du pays ; ce que j'y trouvai de meilleur, ce fut une quantité de manuscrits goths et arabes très bien conservés.

[Vi besökte biblioteket. Munkarna påstod att det omfattade tjugotusen band, nästan alla inbundna i pergament, såsom brukligt är i landet. Det 
intressantaste som jag fann var en mängd mycket välbevarade gotiska och arabiska handskrifter.]

Lidforss blir mycket entusiastisk och i ett brev till hustrun den 10 januari 1868 skriver han:

Du känner mina funderingar om gotiska manuskript i Spanien, ej ensam ty tyskarna har haft folk uti Spanien, men de har rest mest i Leon och det gamla Kastilien. Tänk bara om det skulle bli mig förunnat att bli ett redskap för att verkligen få fram dessa gamla saker i dagsljuset och riktigt på allvar kunna hjälpa vetenskapen ett stycke framåt. En dag ska det väl även bli min tur att åka ut och då är det säkert att jag tar genasta vägen till klostret i Sevilla. Men till dess skola vi få vara tysta som råttor. Om jag ändå hade dig här att få kyssa och omfamna dig och bära dig i procession $i$ hela våningen $i$ glädje!

Hustrun yttrar dock tvivel, inte sälja björnen förrän den är skjuten, men maken är envis och förklarar att han skulle till Sevilla om han så skulle krypa dit på sina bara knän (Beyer 1968: 21). En resa till Spanien under mer gynnsamma omständigheter möjliggjordes av ett resestipendium som Lidforss fick följande år. Man kan säga att Lidforss kom att följa i språkforskaren och orientalisten Johan Gabriel Sparwenfelds fotspår. Denne hade på kungens uppdrag 1689 rest till Spanien för att leta efter spår efter goterna, dock utan att kunna finna några handskrifter (Söhrman 2000: 196). Att intresset för gotiska var levande hos Lidforss kan även utläsas av att han föreläste över gotiska i Lund (Sundell 2015: 82). Som en kuriositet kan i detta sammanhang nämnas att Lidforss 1974 föreslog att fornordiska skulle införas på schemat redan i elementarundervisningen för att stärka det nationella sinnelaget (Lidforss 1874).

Lidforss fick tjänstledigt för ett år framåt, och i maj 1869 ger han sig av på sin stora resa. Breven som han skrev till hustrun är bevarade i Lunds universitetsbibliotek och där kan man följa hans glädjeämnen och vedermödor nästan dag för dag, vilket innebär att det finns över hundra brev. Breven hänför sig huvudsakligen till vistelsen i Madrid. Ett brev som innehåller uppgifter om hans arbete är följande som Lidforss skriver från Madrid i den 15 juni 1869: 
$\mathrm{Nu}$ har jag äntligen klart för mig hur det hänger tillhopa med de gotiska handskrifterna här i Spanien och, om jag blivit narrad på dem, vilket Gudnåd är fallet, så må det ursäkta mig, då så många andra bättre karlar än jag, till och med Diez, blivit det, ja då snart sagt det endast varit en enda människa, nämligen Amador de los Ríos som haft ordning på sakens egentliga sammanhang. Detta kom jag underfund med i går natt då jag läste hans litteraturhistoria där han gör noga reda på allt dithörande. Enligt honom förhåller det sig nämligen så att alla gotiska handskrifter efter 3:e kyrkomötet i Toledo blev såsom arianska och kätterska av konung Leovigilds samlade och uppbrända. Åter en oersättlig förlust till följd av religiös ofördragsamhet som så många andra gånger berövat oss flera bland litteraturens yppersta alster. Vad som nu här går under namnet gotiska handskrifter är inte med Ulfilas bokstäver såsom Codex Argenteus i Uppsala, utan med en annan slags skrift, som betydligt avviker såväl från denna som från annan medeltidsskrift och som bibehålls till 1099. Detta är nu visserligen ett hårt slag men på vilket jag dock i enlighet med fars råd hade gjort mig beredd. Emellertid stannar jag nu i Madrid. Talar om hertigen av Osunas bibliotek där det finns två handskrifter av Roman de la Rose. Ska inte ligga på latsidan utan med Guds makt ska denna resa lända mig till ordentlig båtnad så att jag hoppas att statens pengar inte ska vara bortkastade.

Och det blev statens pengar verkligen inte. Lidforss ger sig med stor energi i kast med andra uppgifter, vilket resulterar i utgivningen av två medeltida texter: El misterio de los reyes magos, Leipzig 1871 samt La estoria de los godos i två volymer i Lund 1872-1873, en översättning från latin till aragonesiska (Gille 2015: 144). Senare ger Lidforss ut Historia de Fray Gerundio de Campazas, Leipzig 1885 och 1896 utkommer i Lund en upplaga av Los cantares de mio Cid i två volymer.

Vistelsen på kontinenten kom att vara 14 månader och under tiden bodde fru och barn hos svärföräldrarna i Norrköping. Efter kortare uppehåll i Frankrike och Italien, där han hittar en text att ge ut, Bonvesin da Rivas Tractato dei mesi (Bologna 1872), kom Lidforss fram till Paris och han skriver till hustrun den 26 juni 1870 :

Besökt Gaston Paris, en ung men mycket framstående vetenskapsman, som min vän Paul Meyer introducerade. Inte gjort så stora saker i Frankrike, 
men detta har blivit omtyckt. Disputatsen om Ronsard har gett mycket beröm. [...]. Kan visa att mina arbeten blivit överallt i utlandet väl bedömda. Detta lull-lull med Carlos III och Vetenskapsakademien i Barcelona tänker jag inte taga fram hemma förrän då när striden skall stånda, så torde det i stället då göra så mycket bättre verkan.

Man kan inte annat än häpna över den vittfamnande verksamhet som Lidforss ägnar sig åt. Han befinner sig på kontinenten under en orolig tid. I Spanien var det politiska läget oklart med en ny kung från Italien och Italien var inbegripet i slutfasen av enandet. I juli 1870 utbryter det fransk-tyska kriget, men då hade Lidforss återkommit till Sverige. Av dessa skeenden märks inte så mycket i breven, men på ett område kan man märka ett mer personligt engagemang, nämligen Katalonien. I ett brev från Barcelona den 5 mars 1870 till hustrun skriver Lidforss:

Edvard har det för övrigt mycket bra i Barcelona. Han har kommit in i en krets av de snällaste, hyggligaste människor man kan tänka sig, skalder och författare allesammans, men icke på spanska, utan på katalanska och den dialekten som står provensalskan ganska nära, håller jag nu på att taga lite reda på, som en förberedelse till provensalskan och när jag så fått egna en månad i Montpellier åt denna och får titta över ett tag till Italien, så tror jag ändå att på sätt och vis att jag skall komma till något helt i fråga om de romanska språken. För övrigt hör det till min gudomliga tur att här överallt i Spanien omfattas med en välvilja som är över all beskrivning och den där artikeln i La Revista har jag fått höra så mycket om att jag riktigt skäms, ty de hederliga människorna, och bland dem många som hava ett riktigt gott namn, behandla mig som en jämlike och tro att jag duger något och jag tycker att det är så skamligt när jag vet med mig själv hurudant det är beställt i själva verket.

Dessa här catalanare äro för övrigt den präktigaste samling av vackra huvuden, och de skola allt få lov att ge mig sina porträtter allesammans, och du skall få se det gör en människa gott i själen blott att betrakta dem; och sedan att höra dem, ack!

Den 22 mars skriver Lidforss från Montpellier där han nämner att han fått orden Carlos III undertecknat av Sagasta och Regenten, och framhåller att "denna har en smula bättre anseende än orden Isabel la Católica som på sistone delats ut till höger och vänster”. 
En vecka senare, den 29 mars, kommer ytterligare ett brev från Montpellier:

Med studiet av provensalskan vill det däremot ej gå riktigt bra. Katalanskan kunde jag lätt nog sätta mig in i. Den har en bestämd ortografi, språket talas av alla, även de högsta klasserna och med ett ord en fullt jämbördig syster till spanskan, italienskan och andra romanska språken. Här däremot talas franska av alla, även av folket vilket endast sinsemellan begagnar provensalskan och härtill kommer att denna provensalska är sig betydligt olik i de olika städerna, ja t.o.m. i skilda kvarter av samma stad. Hela den litterära rörelsen här har därför enligt min tanke ingen stor framtid, utan kommer förmodligen att avstanna med Roumanille och Mistral, och vore det inte för den gamla provensalska poesins ofantliga vikt, skulle man sannerligen inte bråka mycket med hela saken. Emellertid har jag gjort vad jag kunnat, i går afton var jag på min första lektion i en hederlig skräddarfamilj, som först hjälpt upp min rock och sedan, när de fick höra att "monsieur était du côté de la Normandie" och ville lära sig patois, godhetsfullt beviljade mig sin "Ugenie", en flickslinka i de värsta slynåren, men som går i pension till lärarinna. Madame själv var dock den mest intresserade och talade patois oavbrutet i ett sträck hela tiden, utan att jag naturligtvis begrep tiondelen. Kortspel blir en metod för inlärning. Här finns ingen grammatik och något måtte jag väl kunna inhämta.

Detta brev är dessvärre det enda som direkt hänför sig till Katalonien. Dock får man lite mer upplysningar genom en serie artiklar som en katalansk läkare, Benet Roura i Barrios, 1906 publicerade i El Poble Català under rubriken Catalanòfils, där han bland ett antal europeiska romanister som sysslar med katalanska även ägnar en artikel åt Lidforss. Där beskriver Barrios hur Lidforss 1870 etablerar kontakter med kretsen kring la Jove Catalunya, en förening som verkade för den katalanska litteraturen men som även hade en politisk profil. Inspirationen kom från Mazzini och romantiken och den kan räknas som det första uttrycket för en katalansk självständighetsrörelse. I denna krets fanns dramatikern Àngel Guimerà och Víctor Balaguer, verksam som historiker och politiker, samt inte minst Gayetà Vidal. Gayetà Vidal i de Valenciano var professor i historisk geografi vid universitetet i Barcelona och 1889-1893 preses för Reial Acadèmia de Bones Lletres de Barcelona och en framträdande representant för den katalanska litterära och kulturella rörelsen 
som kallas la Renaixença. Lidforss hade uppenbarligen särskilt nära kontakt med Vidal och Barrios berättar hur Lidforss en dag sade till Vidal att han skulle åka tillbaka till Sverige och att han skulle komma och säga adjö om två veckor. När två veckor hade gått kom Lidforss tillbaka och berättade att han hade suttit på sin kammare och studerat katalanska och att han nu kunde tala språket. Det måste dock sägas att de brev som Lidforss skrev till sina kontakter i Katalonien alla är skrivna på spanska.

Lidforss underhöll en livlig kontakt med Katalonien länge efter sin resa. 1877 publicerar Lidforss en artikel med titeln Nykatalansk vitterhet i tidskriften Framtiden (Lidforss 1877: 543-559). Lidforss talar först om bygdemålslitteraturen och nämner den provensalska med Roumanille och Mistral, den på lågtyska med Reuter, nynorskan samt sicilianskan med Pitré. Enligt Lidforss är Europas gamla kulturspråk inte längre lämpliga för att behandla yttringar av ett liv som inte harmonierar med den bokliga bildningen. Detta är dock inte fallet med den litteratur som uppblomstrat i Katalonien. Visserligen är kastiljanskan som Lidforss påpekar

ett gammalt kulturspråk och dess litteratur, ännu till stor del outgiven, hör till de rikaste något land kan uppvisa, men det besitter ännu all önsklig ungdomsfriskhet. Allt vad som diktats och skrivits på katalanska skulle lika väl kunnat skrivas på kastiljanska.

Men det finns historiska och politiska skäl som förklarar det katalanska språkets ställning. Därefter följer en historisk redogörelse, där Lidforss särskilt framhåller att trots en nedgång efter medeltiden så bibehölls landets författning till tronföljdskriget då den avskaffades, och för detta blev den nye kungen Filip V aldrig förlåten. Lidforss nämner diktare som Aribau och Rubio i Ors (Lo Gayter de Llobregat) vilka inledde den nykatalanska litterära pånyttfödelsen. Han redogör sedan för återupprättandet av blomsterspelen, Jocs florals, enligt medeltida mönster. Lidforss framhåller att det nu kan sägas att det finns en katalansk press, katalanska skalder, katalanska prosatörer, samt en katalansk teater som lockar en utvald och talrik publik.

Historiska minnen utgör enligt Lidforss basen för denna vittra pånyttfödelse, och deras brännpunkt utgörs av den gamla strålande och ärorika aragonska kronans härlighet. "Sättet att göra sig den tillgodo kan dock arta sig olika, därav två skolor, enligt den franske provensalisten Charles de 
Tourtoulon, traditionalistiska och anti-traditionalistiska. Den senare behöver handling och strid. Under den litterära formen vill hon känna den moderna idén pulsera och om den framkallar det förflutna så är det för att stadga dess rätt i framtiden. Balaguer är denna skolas främste man. Balaguer beskrivs som en alltigenom hederlig person vars program omfattar frihet grundad på ordning och rätt grundad på plikt." Lidforss menar att Balaguers historiska dramer gör att han artar sig till sitt lands Shakespeare. Andra namn som Lidforss nämner är Francesc Pelay Briz och Francesc Maspons, som arbetat med folksånger och folksagor, samt givetvis Gayetà Vidal, vars intressen för folksederna låg helt i linje med Lidforss egna. Slutligen konstaterar Lidforss i sann idealistisk anda: "Vi har i denna företeelse icke kunnat upptäcka annat den allvarligaste strävan hän mot det goda, sanna och sköna, därför värd all aktning och sympati och vi kunna för vår del ej annat än på det varmaste instämma i den önskan som uttalades för snart 300 år sedan av en vän till historikern Jeroni Pujades: Puix parla en català, Déu li’n don Glòria!” (Eftersom han talar katalanska, måtte Gud ge honom ära). Det förtjänar även att framhållas att denna artikel publicerades på katalanska i tidskriften Lo Gay Saber 1878 där dessutom en berättelse av folklivsforskaren Nils Gabriel Djurklou i katalansk översättning trycktes.

Det är belysande att jämföra med Theodor Hagbergs bok Den provençalska vitterhetens återuppståndelse som kom ut redan 1873. Resonemanget är snarlikt. Även här är det tal om en lysande forntid som provensalerna inte kan glömma, en tid då deras språk var de nyeuropeiska skaldernas modersmål. Hagberg nämner Roumanille som beslutat att "åter bringa sitt glömda och föraktade modersmål till heders och att med naturfriska, men sedesamma sånger på detsamma ersätta de slagdängor, som med råa och ohöviska uttryck nu dödade blygsamheten i barnens öron". Han citerar även Jasmin: "Lärda fransmän dömde för 300 år sedan språket till döden, men det lever ändå..." Men Mistrals språk liknar dock enligt Hagberg mer en volgare illustre och han tror inte på någon framtid för Mistrals företag. Den nationella känslan som driver dessa blommor måste skaffa sig motsvarande uttryck på alla andens övriga områden. Dessutom påpekar Hagberg att det är svårt att inse hur detta skulle kunna ske utan att den franska staten ånyo skulle splittras och att södra Frankrike skulle förenas med Katalonien. Detta tror visserligen inte Hagberg är en trolig utveckling, men han hänvisar till det tyranni som 
Paris utövat över landsorten, det sedefördärv och den sociala upplösning som spridit sig därifrån. Detta förhållande berättigar Mistrals manliga sånger, men något politiskt syfte kan denna opposition mot Paris inte gärna ha. Hagberg påpekar att Frankrikes alltid påpasslige och förtänksamme fiende, Tyskland, inte har försummat att undersöka nejdens beskaffenhet, om den kunde erbjuda några fördelar vid ett anfall. Men visst skulle provensalskans över 10 miljoner talare kunna få använda sitt språk i undervisningen och i kyrkan. En ungdomlig friskhet och en sedlig anda har tillförts den blaserade franska vitterheten, och även om det provensalska språket skulle dö bort, så menar Hagberg att det har gjort en stor insats för att väcka folkets känslor för sedlighet inom familjen, lagbunden frihet inom samhället och tro på himmelska sanningar. Detta arv lämnat åt den franska vitterheten kommer att utgöra ett av den bortdöende provensalska vitterhetens skönaste minnen.

Lidforss ser däremot inte alls några liknande politiska eller moraliska problem i samlevnaden mellan det katalanska och det spanska. Detta blir särskilt tydligt i de brev som Lidforss skrev till Víctor Balaguer. Víctor Balaguer var en av den katalanska kulturella pånyttfödelsens främsta representanter. I sin Historia de Cataluña y de la Corona de Aragón förespråkar Balaguer en federal monarki och han går t.o.m. så långt som att hävda att det hade varit bättre om Aragonien hade blivit den dominerande parten vid bildandet av Spanien. Tanken att medelhavskulturen står för framsteg och frihet återkommer ofta hos Balaguer. 1884 grundades Biblioteca Museu Víctor Balaguer i staden Vilanova i La Geltrú söder om Barcelona och det är i dess arkiv som Lidforss brev finns bevarade. Det är oklart hur Lidforss kom i kontakt med Balaguer. I ett brev den 20 januari 1901 till Carl David af Wirsén meddelar han att Víctor Balaguer avlidit. Lidforss framhåller att han är hedersledamot av Balaguer-institutet, men han kände Balaguer dock inte personligen, vilket inte hindrar att denne hedrat Lidforss med en vänskap som visat sig på många sätt och vid många tillfällen. Om Balaguer säger Lidforss att han var ”... en i alla stycken hederlig människa”. Denna beundran går igen i breven. Så skriver Lidforss till Balaguer den 4 januari 1876 med anledning av att två av Lidforss barn avlidit under året:

Bien sabe usted con motivo de tales perdidas el corazón está siempre más abierto a lo bueno y lo bello, y así creo haber apreciado con más intimidad 
sus sublimes poesias y la fidelidad que muestra hacia la lema catalana: Patria Fides Amor. Dios bendiga a Espana a usted y a todos sus nobles hijos.

[Ni vet mycket väl att då man genomlevt sådana förluster så är ens hjärta alltid mer mottagligt för det goda och det vackra och således tror jag att jag i mitt inre har kunnat uppskatta era sublima dikter och den trohet ni visar det katalanska mottot: Fosterlandet, Troheten och Kärleken. Gud välsigne Spanien, er och alla dess ädla söner.]

Den 13 november 1878 skriver Lidforss angående den nykatalanska rörelsen:

Las simpatias que me ha merecido todo ese movimiento, especialmente usted como primer representante que ha llevado muy alto las barras de Cataluña, al par que sabido ser federal para unir y no para dividir, promover la libertad fundada en el orden y el derecho basado en el deber. Ojalá fuesen tan sesudos y comedidos todos los poetas y hombres políticos de mi querida España, y no tardaría mucho en recobrar su alta posición.

[Den sympati som i mitt tycke hela denna rörelse har förtjänat, särskilt ni själv såsom dess främste representant som har hållit Kataloniens fana mycket högt, som även visat sig kunna vara en federal enhet, inte för att splittra utan för att ena och för att främja den frihet som grundas på ordning och den rätt som grundas på plikten. Om blott alla diktare och politiker i mitt kära Spanien vore lika sansade och måttfulla, då skulle det inte dröja länge förrän Spanien återvann sin höga ställning.]

Den 3 maj 1894 skriver Lidforss om ett projekt att förse biblioteket som hör till Casa Museu Balaguer med en samling böcker på svenska. I ett brev skriver Lidforss:

Espero que el proyecto de mí ideado de establecer en la Biblioteca Museo Balaguer un compartimiento sueco y un punto céntrico por los que quieran ocuparse de nuestra lengua y literatura no tardará a verificarse de una manera que corresponde perfectamente a mis deseos.

[Jag hoppas att det inte kommer att dröja länge innan det av mig initierade projektet att i Balaguermuseet inrätta en svensk avdelning och ett centrum för dem som önskar ägna sig åt vårt språk och litteratur förverkligas helt och hållet enligt mina önskemål.] 
I samma brev meddelar Lidforss även att han har 100 böcker till en grundplåt som de främsta förläggarna har givit som gåva. Det finns även böcker från Finland där, som Lidforss framhåller, de bildade klasserna fortfarande talar svenska. Balaguer har talat med en bekant som har ett skepp som ska anlöpa en svensk hamn. Det finns kanske människor som förlöjligar idén att ha svenska böcker i Spanien, men vi har en betydande litteratur och det är inte mer absurt för en svensk att studera spanska än för en spanjor att studera svenska. Lidforss framhåller att det också är fråga om att återgälda den tacksamhetsskuld som han har gentemot Balaguer för den stora godhet och ädla sinnelag denne visat honom. Böckerna avspeglar Lidforss smak och mycket riktigt finns både Runeberg och Topelius representerade, liksom August Blanche och Svenska folkvisor utgivna av E. G. Geijer och A. A. Afzelius. Lidforss översatte två pjäser av Balaguer, Romeo och Julia och Hannibals död, men de kom aldrig att sättas upp på någon svensk scen. Den sistnämnda publicerades dock i tidskriften Ute och hemma 1894. Inte heller den översättning av pjäsen Terra Baixa som gjorts på uppdrag av Dramaten kom att spelas, men Karl August Hagberg publicerar den dock i sin antologi Modärna Trobadurer som utkom 1917. Karin Monié framhåller att Lidforss själv menade att han egentligen aldrig velat ägna så mycket tid åt översättning av dramatik, hans arbetssätt tillät det inte: "Jag är för samvetsgrann eller pedantisk eller hur man vill kalla det och arbetar för långsamt" skriver Lidforss till Dramatenchefen Gustaf Fredriksson. Onekligen ett självkritiskt omdöme av en som gjort en storartad översättningsbragd med två av världslitteraturens huvudverk, Dantes Den gudomliga komedin och Cervantes Don Quijote.

Som emeritus flyttade han till Stockholm, där han den 1 oktober 1901 blev medlem av Svenska Akademiens Nobelinstitut som specialist på fransk och spansk litteratur. Arbetet gav honom visst inflytande över det nyinstiftade Nobelpriset i litteratur, bland annat priset till José Echegaray och Frédéric Mistral 1904. Som expert på katalanska fick han en för honom säkert mycket välkommen uppgift, nämligen att under åren 1907-1910 skriva sakkunnigutlåtandena om Àngel Guimerà som då var föreslagen till Nobelpriset. För en detaljerad redogörelse för omständigheterna kring Guimeràs kandidatur till Nobelpriset hänvisas till Enric Gallén och Dan Nosell (2011). Det första utlåtandet 1907 är mycket omfattande och som 
så ofta i den tidens anda framhålls de "idealiska" aspekterna. Så skriver Lidforss att inte en rad i Guimeràs verk antyder att han velat göra det onda attraktivt och angenämt. Förutom att Guimerà uppfyller alla krav på att kunna utarbeta ett drama, har han särskilt ett stort hjärta som klappar för mänsklighetens högsta ideal. Enligt Lidforss är Guimerà säkerligen en av tidens främsta representanter för en högtidlig och ädel litteratur. Han citerar den engelske hispanisten Fitzmaurice-Kelly som menar att på senaste tiden har Echegaray visat sig underlägsen Guimerà som dramatiker.

Echegaray hade ju fått ett delat Nobelpris 1904 och då hade Lidforss skrivit utlåtandet. Lidforss uppfattning om Echegaray framgår av en artikel som Lidforss skrev 1902. Där framgår att Lidforss inte är särskilt entusiastisk, men "kärnan i hans dramer är fullkomligt frisk och de präglas alltigenom av en verklig ädelhet i känslor och tänkesätt". Lidforss hade säkert föredragit att Guimerà fått priset, men 1904 var Guimerà inte föreslagen. Även om Guimerà kan ha haft vissa utsikter att få priset fram till af Wirséns död 1912, stötte hans kandidatur därefter på ett allt större motstånd i Akademien. Som sakkunnig förefaller Lidforss ha varit helt samstämmig med af Wirsén. Ett bevis på detta är ett brev till Viktor Rydberg av den 23 november 1887 där Lidforss, apropå sin då 19-årige son Bengt, talar om "den osunda och delvis rentav vämjeliga rörelsen bland ungdomen". Dessbättre har Rydbergs dikter dock haft en välgörande inverkan på sonen, men till Lidforss stora förtret har sonen i alla fall af Wirsén som sin "bête noire".

Lidforss avled i Stockholm 1910. Enligt Karin Moiné ställs han i dödsrunorna i paritet med Carl August Hagberg, men här och var skymtar också en kvardröjande misstro mot den som inte rimmade Den gudomliga komedin. Lidforss dotter Hedvig Lidforss-Strömgren påminde sig om hur fadern under de sista dagarna i livet ofta tänkte på Spanien och Katalonien: "Spanien fyllde tankarna i sjukbädden. Red han på en mulåsna genom Andalusien? Språkade han med sina kära katalanska vänner som i hans ungdom hade behandlat honom som jämlike? Vi fick aldrig veta det, men han anförtrodde sin hustru att - nu reste han till Spanien!" 


\section{Bibliografi}

Icke tryckta källor:

Biblioteca Museu Balaguer

Kungliga biblioteket, brevskrivarregistret

Lunds universitetsbibliotek, Lidforsska papperen

Tryckta källor:

Barrios, Benet R., 1906: Catalanòfils. Edvard Lidfors [sic]. El Poble Català 73, 31-III-1906.

Beyer, Nils, 1968: Bengt Lidforss. Stockholm: Norstedts.

Comas i Güell, Montserrat, 2007: La Biblioteca Museu Balaguer, un projecte nacional català. Publicacions de l'Abadia de Montserrat (Textos i Estudis de Cultura Catalana, 120).

Franzén, Olle, 1977-1979: Svenskt biografiskt lexikon 22. 697.

Gallén, Enric \& Nosell, Dan, 2011: Guimerà i el premi Nobel, història d'una candidatura. Lleida: Punctum.

Geijerstam, Regina af, 1982: El català a Escandinàvia, Estudis de llengua i literatura catalanes IV, El català a Europa i Amèrica. Abadia de Montserrat.

Gille, Johan, 2015: Los lingüistas suecos y la Filología aragonesa. Archivo de filología aragonesa $71.141-157$.

Hagberg, Theodor, 1873: Den provençaliska vitterhetens àteruppståndelse i det nittonde århundradet. Uppsala: Edqvist.

Hagberg, Karl August, 1917: Modärna Trubadurer: Ur den nykatalanska diktningen i varra dagar. Lund: Gleerups.

Labat, Jean-Baptiste, 1927: Voyages du Père Labat en Espagne 1705-1706. Paris: Editions Pierre Roger.

Lidforss, Edvard, 1860: Tysk grammatik för elementarundervisningen. Örebro.

Lidforss, Edvard, 1863: Tyska läs- och skriföfningar för elementar-undervisningen. Örebro.

Lidforss, Edvard, 1867: Fransk språklära för elementar-undervisningen med inflickade läs- och skriföfningar. Stockholm: Hæggström.

Lidforss, Edvard, 1871: El misterio de los Reyes Magos. Jahrbuch für Romanische und Englische Literatur, XII/1, 2 vols. Leipzig: F.A. Brockhaus.

Lidforss, Edvard, 1874: I läroverksfrågan. Lund: Gleerups förlag.

Lidforss, Edvard, 1877: Nykatalansk vitterhet. Framtiden. 543-559.

Lidforss, Edvard, 1882: Viktor Balaguer. Ny illustrerad tidning, 18.2. 65-66.

Lidforss, Edvard, 1895-1896: Los cantares de Myo Cid, 2 vols. Lund: Lunds universitet. 
Lidforss, Edvard, 1902: José Echegaray som dramaturg. Nordisk tidskrift for vetenskap, konst och industri. 593-610.

Lidforss-Strömgren, Hedvig, 1926: Med prof. E. Lidforss i Dalarna - och i Spanien. Hågkomster och livsintryck 7. 220-228.

Michaëlsson, Karl, 1961: Les études provençales en Suède. Actes et mémoires du II :e congrès international de langue et littérature du Midi 1958. 257-261.

Moiné, Karin, u.å.: Edvard Lidforss, 1833-1910. I: Svenskt översättarlexikon. http://www.oversattarlexikon.se/artiklar/Edvard_Lidforss. [2017-10-15]

Sundell, Lars-Göran, 2002: Romansk brytpunkt - kring Jacob Theodor Hagberg. I: Bartning, Inge et al. (red.), Mélanges publiés en hommage à Gunnel Engwall. Stockholm: Acta Universitatis Stockholmiensis, Romanica Stockholmiensia 20.

Sundell, Lars-Göran, 2011: Nyeuropeisk lingvistik och modern litteratur. Årsbok, Kungl. Humanistiska Vetenskaps-Samfundet i Uppsala. 45-66.

Sundell, Lars-Göran, 2015: Den tidiga romanistiken i Lund. Annales Societatis Litterarum Humaniorum Regiae Upsaliensis.

Svensén, Bo (red.), 2001: Nobelpriset i litteratur: nomineringar och utlàtanden 1901-1950. Stockholm: Norstedts.

Söhrman, Ingmar, 2000: Gothicism - the final flourish of a long history. I: Encuentro Histórico España-Suecia (2000: Uppsala): Relaciones entre España y Suecia desde mediados del siglo XVII hasta comienzos del XIX: simposio en Uppsala, 20-24 septiembre 2000: actas = Spanish-Swedish relations from the mid seventeenth century to the early nineteenth century: symposium in Uppsala, 20-24 september 2000. 187-199. 